\title{
ANALISIS SISTEM E-COMMERCE PADA PERUSAHAN JUAL-BELI ONLINE LAZADA INDONESIA
}

\author{
Galih Setiyo Budhi \\ Pendidikan Teknik Informatika UNY \\ Email: setiyo.galih@gmail.com
}

\begin{abstract}
ABSTRAK
Tujuan dari penulisan paper ini adalah untuk menganalisis mengenai system e-commerce pada situs belanjan online terbesar di Indonesia yaitu Lazada.co.id. Analisis meliputi, kelebihan dan kekurangan dari lazada Indonesia serta analisis SWOT pada situs tersebut. Hasil analisis menunjukan bahwa lazada Indonesia mampu menjadi perusahaan belanja online terbesar di Indonesia dengan berbagai kelebihan pelayanan maupun jaminan keamanan transaksi. Namun, lazada juga masih memliki beberapa kelemahan, diantara mengenai security system, dengan masih banyaknya konsumen yang mengalami penipuan. Perusahaan lazada Indonesia menggunakan strategi iovation, bargaining power of consumer dan bargaining power of suppliers untuk menjadikan perusahaan belanja online terbesar di Indonesia.
\end{abstract}

Kata kunci : e-commerce, lazada.co.id

\section{PENDAHULUAN}

Perkembangan internet yang pesat memberi pengaruh yang signifikan dalam berbagai aspek kehidupan, salah satunya dalam dunia bisnis. Penggunaan internet tidak hanya terbatas pada pemanfaatan informasi yang dapat diakses melalui media internet, melainkan juga dapat digunakan sebagai sarana untuk melakukan transaksi perdagangan yang dikenal dengan istilah eletronic commerce atau e-commerce. Industri e-commerce di Indonesia berkembang cukup baik. Perkembangan ecommerce yang cukup baik tersebut tidak terlepas dari jumlah pengguna internet di Indonesia yang meningkat tiap tahunnya. Kemenkominfo mencatat Indonesia berada di posisi ke-8 pengguna internet terbanyak di dunia. Pada tahun 2014, pengguna internet di Indonesia naik hingga mencapai 82 juta. Menurut riset asosiasi e-commerce Indonesia (idEA) dan Google mengenai e-commerce, diprediksi total nilai pasar e-commerce Indonesia mencapai angka US\$ 8 miliar atau sekitar Rp 94 triliun dan akan terus meningkat hingga mencapai angka US\$ 24 miliar atau setara dengan Rp 283 triliun pada tahun 2016 (www.the-marketeers.com).
Angka tersebut membuktikan bahwa Indonesia memiliki pasar yang luas, terlihat dari banyaknya pemain ecommerce yang berasal dari luar negeri. Tidak hanya dari luar negeri, pemain lokalpun juga mencari peluang berbisnis lewat Internet serta mencoba merebut pasar di negeri sendiri. Salah satu cara yang bisa dilakukan perusahaan untuk menarik dan mempertahankan pelanggan adalah dengan memanfaatkan peranan media online sebagai salah satu alat pemasaran (www.themarketeers.com).

Diantara banyaknya layanan ecommerce yang ada di Indonesia, Salah satu yang populer adalah toko online Lazada. Lazada Indonesia didirikan pada tahun 2012 dan merupakan salah satu cabang dari jaringan retail online Lazada di Asia Tenggara. Lazada Asia Tenggara merupakan cabang anak perusahaan jaringan Rocket Internet, perusahaan asal Jerman. Sebagai pendatang baru di bisnis e-commerce Indonesia, Lazada mampu merebut perhatian sebagian besar masyarakat internet (netizen). Menurut penelitian yang dilakukan oleh Nusa Research yang berjudul "E-Commerce Indonesia 2014 Omnibus Popular Brand Index", Lazada merupakan situs ecommerce terpopuler di 
Indonesia saat ini. Berdasarkan situs pemeringkat website Alexa.com, Lazada saat ini menempati urutan ke-11 sebagai situs yang paling sering dikunjungi. Peringkat tersebut menempatkan Lazada di urutan pertama sebagai situs toko online business to consumer (B2C) yang paling sering dikunjungi. (www.alexa.com). Indonesia sempat masuk dalam daftar negara dengan potensi pertumbuhan industri e-commerce yang menjanjikan, namun hal itu tidak membuat perjalanan industri e-commerce Indonesia berjalan lancar begitu saja, bahkan sempat pula dikatakan masih banyak pelaku industri yang merugi. Menurut situs Quartz, penyebab terjadinya dinamika tersebut adalah akses belanja online di Indonesia masih didominasi oleh kalangan profesional. Selain itu masih terbatasnya layanan pembayaran dan keperluan logistik. Kemudian banyaknya pengguna Internet yang tak sejalan dengan tingkat penjualan e-commerce. Indonesia yang dikenal sebagai negara berpenduduk terbanyak keempat di dunia, diketahuimemiliki jumlah pengakses internet yang juga cukup banyak. Namun hal tersebut ternyata tidak berdampak cukup baik terhadap tingkat penjualan ecommerce di Indonesia. Berdasarkan riset situs Quartz, Indonesia berada di posisi paling akhir dari lima negara di Asia perihal peringkat estimasi penjualan e-commerce. Hal ini dapat menunjukkan bahwa minat beli secara online masyarakat Indonesia masih rendah (www.qz.com). Sementara itu, menurut situs Quartz saat ini konsumen Indonesia masih menyukai belanja online lewat cara "konvensional". Meski sudah serba online, ternyata konsumen Indonesia saat ini masih jauh lebih menikmati belanja online dengan cara lama seperti lewat grup di BlackBerry Messenger (BBM), classified marketplace, forum, hingga layanan jejaring sosial seperti Facebook dan lain-lain. Semua layanan ini merupakan sistem belanja online yang bisa mempertemukan antara penjual dan pembeli atau consumer to consumer (www.tekno.kompas.com). Masyarakat saat ini juga masih menganggap berbelanja melalui internet memiliki risiko yang cukup tinggi. Menurut survei yang dilakukan Kaspersky Lab dan B2B International, sebanyak 49\% pengguna internet di seluruh dunia merasa rentan saat berbelanja online atau melakukan transaksi secara online.Tingkat perlindungan terhadap penipuan cyber merupakan faktor penting bagi pengguna saat memilih toko online atau operator jasa keuangan (teknoliputan6.com). Berdasarkan survei Google yang berjudul "Business Insight with Google: Pelanggan Online Indonesia", diketahui bahwa faktor keamanan menjadi hambatan terbesar bagi masyarakat untuk membeli barang secara online. Konsumen khawatir akan kualitas barang yang dijual dan keamanan akan data pribadinya. Sedangkan menurut penelitian The Nielsen Global Survey of E-Commerce, keamanan kartu kredit tetap menjadi kekhawatiran utama. Konsumen digital Indonesia sangat berhati-hati jika harus memberikan informasi mengenai kartu kredit mereka secara online. Enam dari sepuluh konsumen mengatakan bahwa mereka tidak bersedia memberikan informasi kartu kredit mereka secara online. Berbagai kekhawatiran diatas merupakan persepsi risiko yang menjadi penghalang potensial dalam melakukan pembelian online. Kim et al., (2007: 546) mendefinisikan persepsi risiko sebagai keyakinan konsumen tentang potensi hasil negatif tidak pasti dari transaksi online. Persepsi risiko dapat mempengaruhi minat beli seseorang melalui internet. Dengan berbagai alasan tersebut, perlu adanya sebuah review dan analisis mengenai system e-commerce pada situs belanja online lazada.co.id. analisis meliputi, kelebihan, kelemahan, dan analisis SWOT terhadap perusahaan online lazada.co.id. 


\section{METODE}

Analisis yang digunakan dalam paper ini adalah anilisi secara deskriptif. Analisis dalam paper ini, dilakukan dengan membandingkan teori-teori e-commerce pada system informasi, untuk mengetahui kelebihan dan kelemahan pada situs jual beli lazada.co.id. selain itu analisis SWOT juga digunakan dalam paper ini untuk memberikan analisa yang lebih mendalam dari situs jual beli lazada Indonesia.

\section{HASIL DAN PEMBAHASAN}

Tujuan dari perusahaan lazada Indonesia adalah menjadi salah satu belanja online yang paling top dan utama di Indonesia serta memberikan pelayanan kepada konsumen secara maksimal, memberikan inspirasi dalam belanja dan memberikan pengalaman kepada konsumen dalam memilih-milih produk online. Karyawan yang bekerja di perusahaan ini merupakan individu yangmempunyai jiwa kewirausahaan, karena mereka berasal dari sekolah bisnis terbaik dan perusahaan di seluruh dunia. Oleh sebab itu tidak diragukan lagi kualitas dalam pemberian pelayanan kepada konsumen yang akan di berikan secara maksimal. Pelayanan yang Lazada berikan memiliki kelebihan tersendiri dalam pasar Indonesia, antara lain

1. Pilihan Produk Berkualitas yang beragam

Di Lazada Indonesia dapat dijumpai 12 kategori produk utama mulai dari peralatan rumah tangga, Elektronik rumah tangga, Handphone \& Aksesoris, Kamera, Komputer, TV, Video \& Audio, Mainan \& Bayi, Kesehatan \& Kecantikan, Tas \& Koper, Olahraga \& Otomotif, Musik \& Instrumen, dan Buku.

2. Penawaran Khusus atau Promo Produk

Dalam belanja online seperti Lazada Indonesia juga sangat memperhatikan dinamika kehidupan masyarakat Indonesia. Berbagai penawaran istimewa dilakukan baik yang tidak bertema maupun yang disesuaikan degan tema. Ini tentu saja menjadi kelebihan dari belanja online karena eksekusi promo secara bersamaan antar tema dalam e_commerce lebih mudah dilakukan disbanding di dalam toko fisik.

3. Layanan Super Untuk Raja

Di dunia online anda adalah raja karena anda tinggal pencet telepon bila ingin menanyakan produk, atau complain mengenai layanan, anda tinggal klik, barang diantar, anda tinggal pilih model pembayaran, atau bahkan anda tinggal minta jam berapa barang harus diantar ke rumah anda, dll. Tidak perlu repot dengan senua hal yang ada dalam belanja konvensional.

Di Lazada Indonesia memiliki banyak layanan luar biasa atau layanan super antara lain :

1. Layanan Telepon Hotline

Anda dapat melepon ke nomor telepon yang tercantum di web.

2. Gratis Biaya Kirim ke seluruh Indonesia

Kini Lazada Indonesia memeberikan gratis ongkos pengiriman di Indonesia bagian barat dan tengah, dengan minimum akumulasi pembelian sebesar Rp 200.000

3. Pengembalian barang dalam 14 hari

Lazada Indonesia memberikan waktu 14 hari kepada para pelanggan untuk melakukan penukaran barang atau pengembalian uang jika terdapat kerusakan atau ketidaksesuain barang pesanan.pengembalian barang dilakukan dengan cara mengisi formulir online di website Lazada kemudian pengembalian barang akan diproses lebih lanjut.

4. Waktu Kirim

Walaupun belum menerapkan waktu kirim hari yang sama (same day delivery), tapi Lazada Indonesia sudah membuktikan kemajuan baik dalam hal layanan pengiriman. Kini pengiriman dilakukan dalam rentang waktu 2-6 hari ke seluruh Indonesia.

Walaupun mengalami hambatan dalam melakukan penjualan di awal - awal pembentukan Lazada Indonesia, pihak Lazada 
sangat merespon dengan sangat baik dengan melakuakn berbagai promo untuk menaikkan keinginan masyarakat berbelanja di dalam situs mereka. Sehingga jika melihat kesuksesan yang diraih oleh Lazada kita dapat menyimpulkan bahwa system E-commerce yang dibawa oleh perusahaan rocket internet dengan anak perusahannya yaitu Lazada sangat diminati oleh para konsumen.

Sedangkan untuk kekuranggan dari Ecommerce Lazada Indonesia adalah :

1. tidak menutup kemungkinan dari costumer yang berkunjung ke web ini dan meragukan integeritas dari situs Ecommerce ini yang dikarenakan nomor customer yang dicantumkan di situs nerupakan nomor provider untuk telepon genggam yang dianggap sama kebanyakan situs / penjual produk bohonggan (penipuan) yang juga tersebar di internet.

2. Respon layanan konfirmasi pembayaran yang masih sedikit terlambat

3. Beberapa produk yang available stock di website ternyata out of stock di gudang

4. Layanan M-Banking dan pembayaran kartu kredit yang belum memiliki integritas tinggi

\section{Analisis SWOT}

1. Strength / Kekuatan : Transaksi antara pembeli dan penjual dilakukan secaracepat, mudah dan murah.

2. Weakness / Kelemahan :

Barang tidak bisa dipegang secara langsung, kadang barang tersebut tidak sesuai dengan yang kita inginkan / beda dengan yang ditampilkan

3. Opportunity / Peluang: Dapat menghasilkan produk baru yang banyak diminati customer / permintaan dari customer, jika produk sesuai, bagus dan memuaskan konsumen otomatis akan laris terjual

4. Threat / Ancaman :

Dikhawatirkan adanya pembuatan website palsu, persaingan harga, kualitas, persaingan secara global, tidak adanya jaminan bahwa transaksi e-commerce terbebas dari upaya perusakan/pemanipulasian data dan tentu akan berdampak pada berkembangnya aktivitas ekonomi.

Apabila merujuk pada buku "Introduction to Infromaton Sistem" dari James A. O'brien dan George M. Marakas, penggunaan system infromasi tersebut merupakan sebuah Inovation, bargaining power of consumer dan juga bargaining power of supplier.

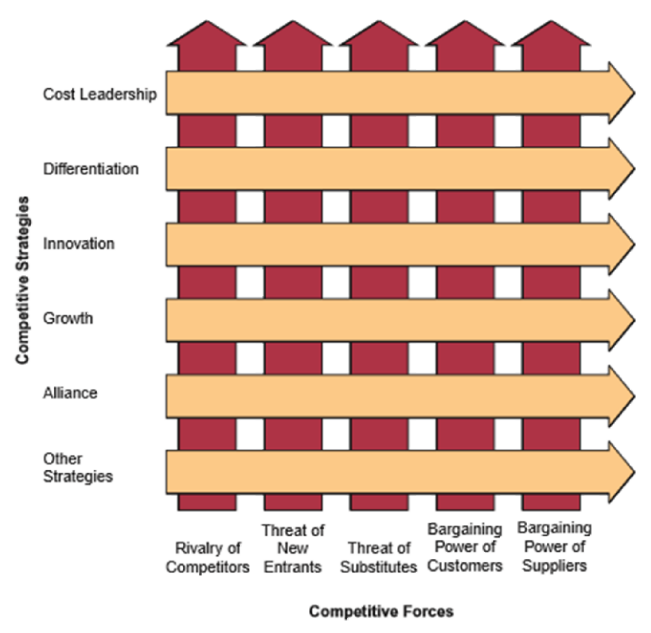

a. Innovation

Perusahaan lazada Indonesia melakukan sebuah inovasi dengan memeberikan pelayanan yang berbeda dari situs-situs jual beli online yang ada sebelumnya. Selain itu lazada juga memberikan jaminan bahwa barang pasti akan dikirim atau jaminan uang kembali jika barang tidak sesuai dengan pesanan. Dengan inovasi tersebut lazada berhasil menjadi situs jual beli terpopupler di Indonesia.

b. Bargaining power of consumer

Perusahaan lazada memanfatkan peluang pengakses internet di Indonesia yang cukup banyak sehingga minat belanja online pun semakin tinggi. Lazada mampu melihat peluang tersebut, sehingga lazada mampu berkembang 
pesat hanya dalam waktu yang cukup singkat.

c. Bargaining Power of suppliers

Lazada menyediakan sekitar 12 jenis kategori produk yang hamper semua dibutuhkan orang. Lazada juga memiliki stok yang cukup sehingga mampu menjadi suplliers yang baik, dengan stok yang cukup. Lazada mampu menyediakan semua kebutuhan masyarakat, sehingga menjadi situs belanja online yang banyak diminati masyarakat.

\section{SIMPULAN}

Berdasarkan hasil analisa, dapat disimpulkan mengenai situs belanja online Lazada Indonesia sebagai berikut :

1. Perusahaan lazada Indonesia menjadi perusahan e-commerce terbesar di Indonesia dengan beberapa kelebihan yang dimilikinya.

2. Perusahaan lazada Indonesia masih memiliki beberapa kelemahan dari segi security system, yang masih rentan terhdap penipuan online

3. Persahaan lazada Indonesia, menggunakan strategi inovasi, bargaining power of consumer dan bargaining power of suppliers untuk mengembangkan perusahaahn tersebut di Indonesia.

\section{DAFTAR RUJUKAN}

---------.2012. "mengulik sejarah lazada Indonesi." Tersedia di http://blog.lazada.co.id/ Diakses pada tanggal 15 Mei 2016.

-------2016. “ asosiasi e-commerce Idonesia." Tersedia di www.themarketers.com. Diakses pada 15 Mei 2016.

2016. "peringkat situs belanja online di Indonesia." Tersedia di www.alexa.com. Diakses pada 15 Mei 2016

James A. O'brien and George M. Marakas. 2010. Introduction to Information System. Mc Graw-Hill Irwin companies.

Kim, D. J., Ferrin, D. L., \& Rao, H. R. (2007). "A Trust-based consumer Decision Making Model in Electronic Commerce: The Role of Trust, Perceived Risk, and Their Antecedents". Proceedings of Ninth Americas Conference on Information Systems.pp157-167. 